\title{
Iç Kontrol Sistemi ve Denetim Programı Etkinliği- Devlet Üniversitelerine Yönelik Uygulama
}

Esin Nesrin CAN' $\cdot$ Cem ÇETiN ${ }^{2}$

Makale Gönderim Tarihi: 31.12.2018

Makale Kabul Tarihi: 12.09.2019

\section{Öz}

Bu makalede devlet üniversitelerindeki iç denetim birimlerinde iç kontrol sisteminin iç denetim programı üzerindeki etkileri ele alınmıștır. iç denetim programı üzerinde iç kontrol sistemi bileșenlerinin etkisi, devlet üniversitelerinde görev yapan iç denetçilere yönelik olarak geliștirilen anket uygulamasıyla saptanmaya çalıșılmıștır. Bu çerçevede denetim programının etkinliğiyle "kontrol ortamı", "kontrol faaliyetleri" ve "izleme" bileșenleri arasında istatistiksel açıdan anlamlı ilișki tespit edilirken; "risk değerlendirme" ve "bilgi ve iletișim" bileșenleri arasındaysa, anlamlı bir ilișki bulunamamıștır.

Anahtar Kelimeler: İç kontrol sistemi bileșenleri, iç denetim program etkinliği, devlet üniversiteleri.

JEL Siniflaması: M420

\section{Internal Control System and Audit Program Activity - Implemantation} For State Universities

\section{Abstract}

In this article, the effects of the internal control system on the internal audit program of the public universities are discussed. The effects of the internal control system components on the internal audit program have been tried to be determined by the questionnaire application developed for internal auditors working in public universities. In this context, a

1 Dr. Öğretim Üyesi, İstanbul Aydın Üniversitsi, ï̈BF İșletme Bölümü, Orcid No: 0000-00023525-0793 (Sorumlu/baș yazar) Mail: esincan@aydin.edu.tr

2 Dr, İç Denetim Birimi Bașkanı, Marmara Üniversitesi, Orcid No: 0000-0002-9530-7288, Mail: cemcetin1977@gmail.com 
statistically significant relationship was found between the effectiveness of the audit program and the "control environment", "control activities" and "monitoring" components; No significant relationship was found between the effectiveness of the audit program and the "risk assessment" and "information and communication" components.

Keywords: Internal control system components, internal audit program activity, state universities.

\section{JEL Classification: M420}

\section{Giriș}

İç denetim 5018 sayılı Kamu Mali Yönetimi ve Kontrol Kanunu ile birlikte kamu sektöründe yer almaya bașlamıș olup; on yıldan fazla uygulama alanı bulmuștur. Temel amacı organizasyondaki iç kontrol sisteminin etkililiğini ölçmek ve değerlendirmek olan iç denetçiler; kurumlarına bu bağlamda güvence ve danıșmanlık hizmeti sunmaktadırlar. Kurumlardaki iç denetim faaliyetinin șüphesiz en önemli ve ilk așaması programlama/planlamadır. İc denetim birimleri/bașkanlıkları kurumsal yapıları ve örgütlenme biçimlerine göre risk bazlı bir anlayıșla yıllık programlar ve üç, beș yıl ya da daha farklı süreleri kapsayan denetim planları hazırlarlar. Öte yandan iç denetim birimleri/bașkanlıkları kurumun örgüt hiyerarșisinde yer aldıklarından kendileri de iç kontrolden etkilenirler. Bu bağlamda iç denetim iç kontrolün etkililiğini değerlendirirken bir yandan da organik olarak organizasyonun iç kontrol sisteminden etkilenir. Bu bağlamda iç denetim plan/programları üzerinde iç kontrol sisteminin etkileri üzerinde durulması gereken bir konu olarak ortaya çıkar.

Bu makalede Türkiye'deki devlet üniversitelerindeki iç denetim birimleri özelinde iç kontrol sisteminin iç denetim programı üzerindeki etkileri ele alınmıștır. Çalıșma kapsamında literatür taramasını takiben uygulanan anket, Fawzi Al Sawalqa ve Atala Qtish tarafından kaleme alınan "Internal Control and Audit Program Effectiveness: Empirical Evidence from Jordan" (Sawalqa \& Qtish, 2012, s. 129-135) adlı çalıșmada yer alan sorulardan yararlanılarak olușturulmuștur. Bu bağlamda, çalıșmada iç denetim programı üzerinde iç kontrol sisteminin etkisi, devlet üniversitelerindeki iç denetim birimlerinde görev yapan iç denetim birim bașkanları ve iç denetçilere geliștirilen anketin uygulanması ile saptanmaya çalıșılmıș olup; bulguların analizi ve değerlendirilmesi "Sonuç" bölümünde sunulmuștur. 


\section{2. İç Kontrol Kavramı}

Yönetimin temel fonksiyonlarından biri olan kontrol, organizasyonların hedeflerinin gerçekleșmesinde yönetim tarafından belirlenen yöntem ve araçları ifade eder. Her organizasyon faaliyetinin planlanması, örgütlenmesi, koordineli bir șekilde yürütülmesi ve sonunda kontrol edilmesi gerekir. Organizasyonun amaçlarına sağlıkı bir biçimde ulașmasını sağlayacak politika ve yönetmelikler bütününü ifade eden kontrol, muhtelif kontrol noktalarını içeren ve prosedürlerde tanımlanan bir süreçtir (ibiș \& Çatıkkaș, 2012, s. 97) (Dabbağoğlv, 2009, s. 109-1 10).

Son yıllarda dünyada yașanan gelișmeler, iș süreçlerindeki hızı değișim ve rekabetçi yapı organizasyonlarda kontrol ve denetimin önemini artırmıștır. Yönetim biliminin kurucusu olarak bilinen Henri Fayol kontrolü, "her șeyin, verilen emirlere ve konulmuș kurallara uygun yapılıp yapılmadığının gözetimi" șeklinde tanımlamakładır. (Tosun, 1992, s. 279) Süreklilik gösteren bir yönetim fonksiyonu olan kontrol, planlamada tespit edilen amaçlarla, fiili sonuçların karșılaștıııldığı ve düzeltici faaliyetlerin yapıldığı, önlemlerin alındığı bir süreçtir.

İç kontrol ile ilgili küresel regülatör organizasyon olan The Committee of Sponsoring Organizations of the Treadway Commission (COSO) 1992 yılında yayımladığı İc Kontrol - Bütünleșik Cerçevesine göre "genelde ișletmenin yönetim kurulu, üst yönetimi ve diğer personeli tarafından etkilenen; faaliyetlerin etkililiği ve verimliliği, finansal raporlamanın güvenilirliği ve ilgili yasalara ve düzenlemelere uygunluk amaçlarına ulașilıp ulașılmadığı konusunda makul güvence sağlamak üzere tasarlanmıș bir süreçtir" șeklinde tanımlanmıștır. COSO bu tanımı 2013 yılında güncellediği İç Kontrol-Bütünleșik Çerçevede "finansal raporlamanın güvenilirliği" ifadesi yerine "raporlamanın güvenilirliği" kavramını kullanarak daha da genișletmiștir (Cömert, 2016, s. 6-7).

İç kontrol kavramı dünyada yașanan gelișmeye paralel olarak Türk kamu yönetimine 2003 ylında yayımlanan 5018 sayılı Kamu Malî Yönetimi ve Kontrol Kanunu bağlamında girmiștir. Belirtilen kanun çerçevesinde yürürlüğe konulan İc Kontrol ve Ön Mali Kontrole Ilișkin Usul ve Esaslara llișkin Yönetmelikte iç kontrol; "idarenin amaçlarına, belirlenmiș politikalara ve mevzuata uygun olarak faaliyetlerin etkili, ekonomik ve verimli bir șekilde yürü̈ülmesini, varlık ve kaynakların korunmasını, muhasebe kayıtlarının doğru ve tam olarak tutulmasını, malî bilgi ve yönetim bilgisinin zamanında ve güvenilir olarak üretilmesini sağlamak üzere idare tarafından olușturulan organizasyon, yöntem, süreç ile iç denetimi kapsayan malî ve 
diğer kontroller bütünü" olarak tanımlanmıștır. Tanımda geçen iç denetim kavramı ise 5018 sayılı Kanunda "iç denetim, kamu idaresinin çalıșmalarına değer katmak ve geliștirmek için kaynakların ekonomiklik, etkililik ve verimlilik esaslarına göre yönetilip yönetilmediğini değerlendirmek ve rehberlik yapmak amacıyla yapılan bağımsız, nesnel güvence sağlama ve danıșmanlık faaliyetidir" șeklinde ifade edilmiștir.

İç kontrol ve iç denetim mevzuatta ve uygulamada birbiriyle ilișkili olgulardır. Denetçi, güvence verme ya da danıșmanlık faaliyeti esnasında organizasyonun iç kontrollerinin yapısı ve de ișleyișinden sağladığı bilgi ve belgelere göre hareket eder. Denetçi iç kontrollerin etkililiğini baz alarak denetim riskini belirler. Etkili bir iç kontrol sisteminin varlığı denetim ișlemlerine -örneğin zaman tasarrufu sağlayarak- etkinlik kazandırır. Öte yandan iç denetim, iç kontroller ile ilgili değerlendirmelerde bulunarak organizasyon yönetimini bilgilendirmekte ve çeșitli önerilerde bulunmaktadır.

İç kontrolün önemi ve faydaları, mevcut iș süreçleri kapsamında; "hata ve hileyi tespit etmek, yasa dıșı uygulamaları azaltmak, ișletmelerin rekabet gücünü geliștirmek, veri kalitesini arttırmak, ișletme altyapısını olușturmayı desteklemek ve bağımsız denetim ücretlerini azaltmak" olarak sıralanabilir (Liu, 2005, s. 93).

- İç kontrol yukarıda sıralanan faydaları sağlamanın yanı sıra bazı sınırlamalara da sahiptir. Bu sınırlamalar, ișletmenin hedeflerine mutlak ulașılmasının sağlanması konusunda yönetim kurulu ve yönetimi engeller.

- İç kontrole ilișkin sınırlamaların temel nedenleri ise așağıda sıralanan faktörlerden kaynaklanmaktadır (COSO, 2013, s. 9).

- İç kontrolün ön koșulu olarak ortaya koyulan hedeflerin kalitesi ve uygunluğu,

- Risklere cevap verme ve kontrolü ele alma konularındaki kararların maliyeti ve faydalarının da dikkate alınmasının gerekliliği,

- İki ya da daha fazla personelin gizli anlașmasıyla kontrolün engellenebilmesi,

- Yönetimin iç kontrol kararlarını çiğneme/yok sayma gücünün olması.

İç kontrolün nitelikleri așağıdaki șekilde sıralanabilir (Akyel, 2010, s. 84-85) (iSMMMO, 2013, s. 18). 
- İç kontrol sistemi bir zorunluluktur: İç kontrol süreçleri uygulamanın amacı, riskin yönetilmesine yardımcı olmak dolayısıyla da ișletmenin hedeflerine ulașmasını sağlamaktır

- İç kontrol sistemi ișletmenin tüm faaliyetlerini kapsar: İç kontrollerin adedi, niteliği ve tarzı, ișletmenin tipine ve karșılaștığı risklere göre farklılık gösterir.

- Iç kontrol sistemi tamamlayıcı bir süreçtir: İç kontrol tek bir olay ya da tek bir durum olmayıp, bir ișletmenin faaliyetlerinin içine nüfuz eden bir dizi eylemdir. Bu eylemler bir ișletmenin faaliyetleri boyunca süreklilik temelinde meydana gelirler.

- İç kontrol sistemi hedeflere ulașmayı kolaylaștırır: Etkin bir iç kontrol sürecinde genel hedefler çok sayıda spesifik alt hedefler, fonksiyonlar, süreçler ve faaliyetler aracılığıyla gerçekleștirilir.

- İç kontrol sisteminde hedefler ile iç kontrol bileșenlerinin ilișkisi çok yoğundur: Bir ișletmenin neyi bașarmaya çalıștığını gösteren asıl hedefler ile bu hedefleri gerçekleștirmesi için nelere ihtiyaç duyulacağını gösteren iç kontrol sistemi unsurları arasında doğrudan bir bağlantı vardır.

- İç kontrol sistemi riskleri karșılamak için makul güvence sağlar: İç kontrol, risklerin ortadan kaldırılmasına yardımcı olabilir ve misyonun yerine getirilmesi ile genel hedeflerin gerçekleștirilmesi konusunda sadece makul güvence olușturur.

- İç kontrolün etkinliği ile ilgili sınırlar vardır: Etkin bir iç kontrol sistemi ne kadar iyi tasarlanırsa tasarlansın ve ne kadar iyi ișlerse ișlesin, ișletmenin hedeflerini gerçekleștirmesi veya ișletmenin varlığını sürdürmesi konusunda yönetime sadece makul güvence sağlayabilir; mutlak güvence sağlayamaz.

- İç kontrol sistemi yönetim ve diğer personel tarafından hayata geçirilir: Yönetim ve her düzeydeki personel ișletmenin misyonunu ve genel hedeflerini bașarması için riskleri karșılayan ve makul güvence sağlayan iç kontrol sürecine müdahil olmak durumundadır. Uygun ve etkin bir iç kontrol sisteminin yapısının kurulması için gerekli unsurların bulunmaması durumunda, iç kontrolün amaçlarına ulașması söz konusu olmayacaktır.

İç kontrol sistemini esas amaçlarına ulaștıracak kontrol önlem ve yöntemleri, üst yönetim tarafından ișletme faaliyetlerinin en küçük birimi olan ișlemler bazında belirlenerek, uygulamaya konulur. Kontrol önlem 
ve yöntemleri ișletmelerde hata ve hilelerin olușabileceği risk noktalarında olușturulur. Yeterli ve etkin kontrol önlem ve yöntemi bulunmuyorsa ișletmenin ișlemlerden, faaliyetlerden zarar görme olasılığı da artar. Bu durum aynı zamanda ișletmenin operasyonlarının verimliliğini ve etkinliğini de azaltabilir (Kiracı, 2003, s. 75).

İç kontrol sisteminin genel ișleyiși, sistemdeki raporlama ve yetki devri akıșları ile iç ve dıș ilgili taraflara düșen görev ve sorumluluklar așağıda yer alan Șekil 1'de özetlenmektedir. Bahsi geçen Sșekil așağıdan yukarıya doğru okunduğunda, kontrol ortamı, yönetim kurulu tarafından ortaya konulan strateji ve politikalar ile kabul edilebilir risk seviyesinin üstüne çıkılmayacağına dair yönetime güvence sunmak üzere geliștirilen bir takım kontrol faaliyetlerini içerdiği görünmektedir. Üst yönetim, iç kontrol sürecinin tasarımından, kurulmasından ve gözetiminden sorumluyken; iç denetçiler sistem ve süreçlerin değerlendirilmesinden sorumludur. Sistemdeki raporlama ve yetki devirlerinin açı olması, sorumlulukların netleșmesi açısından büyük önem tașımaktadır (Erdoğan, 2009, s. 41).

Șekil 1: İç Kontrol Sisteminin İșleyiși

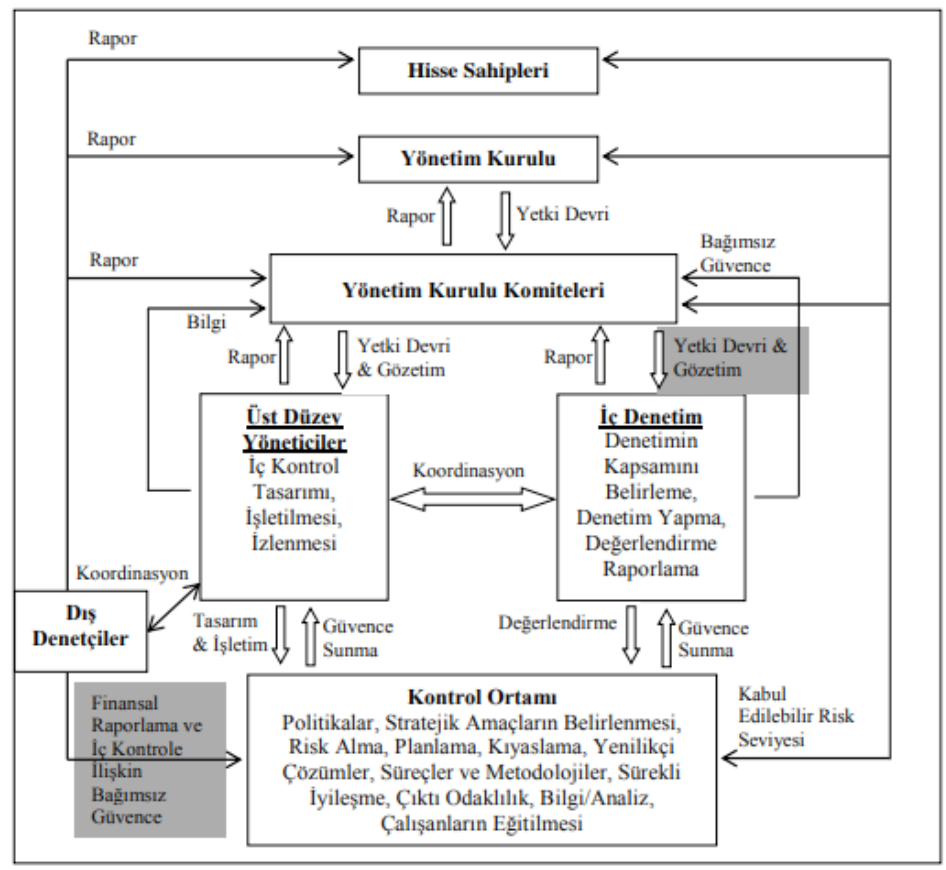

Kaynak: Steven J. Root, Beyond COSO: Internal Control to Enhance Corporate Governance, New York: John Wiley\&Sons Inc., 1998, s. 224'ten Aktaran: Simay Erdoğan, İç Kontrol Sistemi: Kamu İktisadi Teșebbüsleri İçin İç Kontrol Modeli Önerisi, Ankara: DPT Uzmanlık Tezleri Yayın No: 2799, 2009, s. 42. 


\section{Literatür Taraması}

İç denetim programı üzerinde iç kontrol sisteminin etkisi ile ilgili literatür taraması sonucu tespit edilen çalıșmalar așağıdadır:

Bu makalenin konusuna benzer șekilde Fawzi Al Sawalqa ve Atala Qtish tarafindan kaleme alınan "Internal Control and Audit Program Effectiveness: Empirical Evidence from Jordan" adlı 2012 tarihli çalıșmada; iç kontrolün üç bileșeni olan kontrol ortamı, risk değerlendirmesi ve kontrol faaliyetleri ile Ürdün'deki denetim programının etkinliği arasındaki ilișki incelenmișțir. "Denetim programının etkinliğinde, iç kontrol sisteminin farklı bileșenleri katkıda bulunur mu?" sorusunu cevaplandırmayı hedefleyen Sawalqa ve Qtish çalıșmalarında, 43 dıș denetçiye uyguladıkları anket sonucunda, çeșitli kısıtlara rağmen risk değerlendirme bileșeninin denetim programına önemli ölçüde katkı sağladığını buna karșılık diğer iki bileșenin denetim programı üzerinde önemli bir etkisinin olmadığını ortaya koymușlardır (Sawalqa \& Qtish, 2012, s. 129-135). Calıșmamızda ise iç kontrolün beș bileșeni ile denetim programının etkililiği arasındaki ilișki incelenmiștir.

"Evaluation of the Effectiveness of Internal Audit in Greek Hotel Business" adlı çalıșmalarında Theofanis Karagiorgos, George Drogalas ve Nikolaos Giovanis, Yunan otel ișletmelerinde iç kontrol sisteminin beș bileșeni ile iç denetimin performansı arasındaki etkileșimi ele almıș ve yaptıkları ampirik çalıșmada iç kontrol sisteminin tüm bileșenlerinin, iç denetimin etkinliği ve bașarısı açısından hayati öneme sahip olduğu sonucuna varmıșlardır. Bahsi geçen çalıșmanın ayrıca iç kontrol sisteminin bileșenlerinin, iç denetimin performansını nasıl geliștirebildiğini daha iyi anlayabilmede sonraki çalıșmalara rehberlik edeceği de ifade edilmektedir (Karagiorgos, Drogalas, \& Giovanis, 2011, s. 19-35).

Linda S. Mc Daniel "The Effects of Time Pressure and Audit Program Structure on Audit Performance" bașlıklı makalesiyle denetim uygulamalarında zaman baskısının iç denetçilerin performansı üzerindeki etkisi üzerinde durmakta ve ampirik araștırma sonucunda artan zaman baskısının denetim etkililiğini azalttığı sonucuna varmaktadır (Daniel, 1990 , s. 267-280). 


\section{Uygulama}

\subsection{Araștırmanın Amacı ve Gerekçesi}

Hizmet ürünlerinin gerek doğrudan eğitim ve öğretime ilișkin bulunması gerekse çok çeșitli olması nedeniyle devlet üniversitelerinde faaliyet süreçleri ve yönetim fonksiyonları ayrı ayrı büyük önem tașımaktadır. Bu özellikleri ve günümüzde eğitim çıkılarına olan talebin her geçen gün tüm yönleri ile artığı dikkate alındığında, devlet üniversitelerinin etkin ve verimli ișleyișleri üzerine çalıșma yapılmasının önem kazandığı düșünülmektedir. Teknoloji ve iletișimle birlikte, tüm sektörlerde olduğu gibi hızlı bir gelișim ve değișim yașayan bu kurumlarda, iç kontrol sistemlerinin öneminin arttığı, bu çerçevede iç kontrol sistemlerinin denetim programlarının etkinliği üzerindeki rolü de dikkate alınarak, çalıșmanın bu alanda gerçekleștirilmesi ve sürece değer katacak sonuçlara ulașilması hedeflenmiștir.

\subsection{Araștırmanın Örneklemi, Varsayımlar ve Kısıtlar}

Çalıșmada, Türkiye'deki devlet üniversitelerinde iç denetim birim bașkanı veya iç denetçi olarak çalıșan kișilerin tamamı anakütle olarak belirlenmiștir. Bu bağlamda hazırlanan anket 15 Ocak 2018 ile 15 Șubat 2018 tarih aralığında e-posta yoluyla toplam 190 kișiye gönderilmiș fakat 165 geri dönüș sağlanmıștır. Veri giriși esnasında dönüșs sağlayan 10 kișinin yanıtı anket sorularının çoğuna cevap vermemesi dolayısıyla analiz dıșı bırakılmıștır. Uygulama 155 cevap için gerçekleștirilmiștir.

Katılımcıların soruları yanıtlarken gerçek duygu ve düșünceleri ile hareket ettikleri; istekli oldukları, doğru ve eksiksiz biçimde yanıtladıkları kabul edilmiștir. Illaveten yanıt verirken kavramları gerçek anlamıyla anladıklarından hareket edilmiș ve ortaya çıkabilecek kavramsal yanılgılar göz ardı edilmiștir. Anketin internet üzerinde kaldığı bir ay boyunca bazı denetçilerin ankete katılmamaları bir kısı olarak değerlendirilebilir.

\subsection{Veri Toplama Aracı ve Yöntemi}

Çalıșma deneysel olmayan nitel araștırma tasarımına sahiptir ve yapılıș yöntemine göre tarama modelidir. Araștırmada, örneklemden verilerin toplanması bakımından survey modeli (saha taraması) kullanılmıștır. Örneklemden veri toplamada ise, deneklerin görüșlerinin yazılı olarak alındığı bir veri toplama tekniği olan anket tekniği kullanılmıștır. Anket kapsamlı bir literatür taraması sonucunda geçerlilikleri ve güvenilirlikleri daha önce gerçekleștirilen çalıșmalarda onaylanmıș ölçekler kullanılmak suretiyle hazırlanmıștır. 
Ankette yer alan sorular Dana R. Hermanson arkadașalarının "How Effective are Organizations' Internal Control? Inside Into Specific Internal Control Elements" (Hermanson, Smith, \& Stephens, 2012), Fawzi Al Sawalqa ve Atala Qtish'in "Internal Control and Audit Program Effectiveness:Empirical Evidence from Jordan" (Sawalqa \& Qtish, 2012), Theofanis Karagiorgos'un "Evaluation of the Effectiveness of Internal Audit in Greek Hotel Business" (Karagiorgos, Drogalas, \& Giovanis, 201 1), Linda S. McDaniel'in "The Effects of Time Pressure and Audit Program Structure on Audit Performance" (Daniel, 1990), T.C. Maliye Bakanlığı Bütçe ve Mali Kontrol Genel Müdürlüğünün "Kamu liç Kontrol Rehberi (T.C. Maliye Bakanlığı Bütçe ve Mali Kontrol Genel Müdürlüğü, 2014) çalıșmalarından yararlanılarak olușturulmuștur.

Ankete cevap verenlerin, ankette yer alan 14 ifadeye katılma ya da katılmama durumlarını yansıtmak üzere 1= "Kesinlikle katılmıyorum" ile " $5=$ Kesinlikle katılıyorum" arasında değerler içeren 5 'li Likert Cevap Ölçeğinde (Likert, 1932, s. 55) belirtmeleri istenmiștir.

\subsection{Araștırmanın Yöntemi}

Geliștirilen ölçek sonucu edinilen veri matrisi IBM SPSS 22.0 paket programı kullanılarak analiz edilmiștir. Çalıșmada ilk olarak demografik bilgiler bașlığı alında iç denetçiler hakkında genel bilgilere ilișkin sıkık dağııım tabloları sunulmuștur. Ardından ölçek dağılımı ele alınmıș, güvenilirliği ve geçerliliği değerlendirilmiștir. Son olarak hipotezlerin test edilmesi için açıklayıcı faktör analizi (AFA) yapılmıș; elde edilen faktörlere korelasyon ve regresyon analiz uygulanarak ilișkiler belirlenmiștir.

\subsection{Araștırmanın Hipotezleri}

Çalıșmada Kontrol Ortamı (KO), Risk Değerlendirme (RD), Kontrol Faaliyetleri (KF), Bilgi ve Illetișim (Bi), İzleme (IZ), Denetim Programlarının Etkinliği (DPE) boyutlarına yönelik olarak geliștirilen hipotezlere Tablo l'de yer verilmiștir. 
Tablo 1: Araștırmanın Hipotezleri

\begin{tabular}{|c|c|l|}
\hline H & Yol & Hipotez \\
\hline H1 & KO $\rightarrow$ DPE & $\begin{array}{l}\text { Kontrol Ortamının (KO) Denetim Programlarının Etkinliği (DPE) üzerinde } \\
\text { olumlu yönde etkisi vardır. }\end{array}$ \\
\hline H2 & RD $\rightarrow$ DPE & $\begin{array}{l}\text { Risk Değerlendirmesinin (RD) Denetim Programlarının Etkinliği (DPE) üzerin- } \\
\text { de olumlu yönde etkisi vardır. }\end{array}$ \\
\hline H3 & KF $\rightarrow$ DPE & $\begin{array}{l}\text { Kontrol Faaliyetlerinin (KF) Denetim Programlarının Etkinliği (DPE) üzerinde } \\
\text { olumlu yönde etkisi vardır. }\end{array}$ \\
\hline H4 & Bi $\rightarrow$ DPE & $\begin{array}{l}\text { Bilgi ve İletișimin(Bi) Denetim Programlarının Ełkinliği (DPE) üzerinde olumlu } \\
\text { yönde etkisi vardır. }\end{array}$ \\
\hline H5 & IZ $\rightarrow$ DPE & $\begin{array}{l}\text { İzlemenin (iZ) Denetim Programlarının Etkinliği (DPE) üzerinde olumlu yön- } \\
\text { de etkisi vardır. }\end{array}$ \\
\hline
\end{tabular}

\subsection{Bulgular ve Yorumlar}

Anketin güvenirlik düzeyi; Cronbach-Alpha $(C A)=0.926$, Parelel $=0.917$, Strict $=0.921$ olarak ölçülmüștür. Güvenilirlik kriterlerinin her biri \%70 değerini aștığı için, anketin bașarılı ve tutarlı olduğu, edinilecek sonuçların gerçekleri yansıtacağı ortaya konulmuștur. Anketin birinci bölümünde yer alan iç denetçilere yönelik genel bilgiler için elde edilen bulgular așağıdaki gibidir:

Tablo 2: Ankete Yönelik Demografik Soruların Yüzde Dağılımı

\begin{tabular}{|l|c|c|}
\hline Yaș & $\mathrm{N}$ & $\%$ \\
\hline 30'dan Az & 1 & .6 \\
30-40 Arası & 48 & 31.0 \\
$41-50$ Arası & 59 & 38.1 \\
50 'den Fazla & 47 & 30.3 \\
Toplam & 155 & 100.0 \\
\hline Cinsiyet & $\mathrm{N}$ & $\%$ \\
\hline Kadın & 26 & 16.8 \\
Erkek & 129 & 83.2 \\
Toplam & 155 & 100.0 \\
\hline Eğitim düzeyi & $\mathrm{N}$ & $\%$ \\
\hline Lisans & 105 & 67.7 \\
Yüksek Lisans & 48 & 31.0 \\
Doktora & 2 & 1.3 \\
Toplam & 155 & 100.0 \\
\hline Meslek süresi & $\mathrm{N}$ & $\%$ \\
\hline 5 Yıldan Az & 6 & 3.9 \\
5-10 Yıl Arası & 5 & 3.2 \\
11 1-20 Yıl Arası & 66 & 42.6 \\
\hline
\end{tabular}




\begin{tabular}{|l|c|c|}
\hline 20 ve Üstü & 78 & 50.3 \\
Toplam & 155 & 100.0 \\
\hline İç denetçi çalıșma süresi & $\mathrm{N}$ & $\%$ \\
\hline 5 Yıldan Az & 51 & 32.9 \\
$5-10$ Yıl Arası & 46 & 29.7 \\
10 Yıldan Fazla & 58 & 37.4 \\
Toplam & 155 & 100.0 \\
\hline Çalıșılan üniversitede iç & $\mathrm{N}$ & $\%$ \\
denetçi çalıșma süresi & 63 & 40.6 \\
\hline 5 Yıldan Az & 42 & 27.1 \\
$5-10$ Yıl Arası & 50 & 32.3 \\
10 Yıldan Fazla & 155 & 100.0 \\
Toplam & $\mathrm{N}$ & $\%$ \\
\hline Unvan & 37 & 23.9 \\
\hline İç Denetçi Birim Bașkanı & 118 & 76.1 \\
İç Denetçi & 155 & 100.0 \\
Toplam & \\
\hline
\end{tabular}

Ankete cevap veren iç denetçilerin \%6'sı 30 yaș altı, \%3 1'i 30-40 yaș, \%38, 1'i $41-50$ yaș, \%30,3'ü 50 yaș ve üstüdür. Yanıtlayıcıların \%16,8'i kadın, \%83,2'si erkektir. Eğitim düzeyleri; \%67,7 lisans, \%3 1 yüksek lisans, \% 1,3 doktora olarak belirlenmiștir. Meslek süreleri; \%3,9 5 yıldan az, \%3,2 5-10 yıl arası, \%42,6 11-20 yıl arası ve \%50,3 20 yıl ve üzeri biçimindedir. İç denetçi çalıșma süreleri; \%32,9 5 yıldan $a z, \% 29,7$ 5-10 yıl arası, \%37,4 10 yıldan fazla olarak belirlenmiștir. Çalıșılan üniversitede iç denetçi olarak çalıșma süreleri; \%40,6 5 yıldan $a z, \% 21,7$ 5-10 yıl arası, \%32,3'ü 10 yıl üzeri biçimindedir. Görüșülen kișilerin \%23,9'u iç denetçi birim bașkanı, \%76, 1'i iç denetçi pozisyonundadır.

İç kontrolü olușturan bileșenler ile ilgili soruların tasnif edilmesinden olușan -izleyen bölümde gerçekleștirilen faktör analizi yer alan- ölçek dağııımı așağıda gösterildiği gibidir. 
Tablo 3: Ölçeğe Yönelik Cevap Dağılımı

\begin{tabular}{|c|c|c|c|c|c|c|c|c|}
\hline FAKTÖR 1: KONTROL ORTAMI & 1 & 2 & 3 & 4 & 5 & orta & lam & a \pm ss \\
\hline $\begin{array}{l}\text { Soru 1: Üniversitenin etik ilkelere bağlılığı, } \\
\text { üst yönetim tarafından çalıșanlara hem sözle } \\
\text { hem de eylemsel olarak iletilir. }\end{array}$ & 7,7 & 29,0 & 18,7 & 38,7 & 5,8 & 3,06 & \pm & 1,10 \\
\hline $\begin{array}{l}\text { Soru 2: Üniversitenin organizasyonel yapısı } \\
\text { görevler ayrılığı ilkesine dayanmaktadır. }\end{array}$ & 4,5 & 20,0 & 14,8 & 51,6 & 9,0 & 3,41 & \pm & 1,04 \\
\hline FAKTÖR 2: RISK DEĞERLENDIRME & & & & & & & & \\
\hline $\begin{array}{l}\text { Soru 3: Üniversitenin hedefleri sorumlu perso- } \\
\text { nel tarafından kolay anlașilabilir niteliktedir. }\end{array}$ & 3,2 & 29,0 & 25,8 & 40,6 & 1,3 & 3,08 & \pm & 0,93 \\
\hline $\begin{array}{l}\text { Soru 4: Üniversitenin iç kontrol sistemi, kurum } \\
\text { hedeflerine ulașılmasına mani olacak engel- } \\
\text { leri (hile dahil) bertaraf edecek biçimde ta- } \\
\text { sarlanmıștır. }\end{array}$ & 5,8 & 38,7 & 32,9 & 21,3 & 1,3 & 2,74 & \pm & 0,90 \\
\hline FAKTÖR 3. KONTROL FAALIYETLERI & & & & & & & \pm & \\
\hline $\begin{array}{l}\text { Soru 5: Uygun politika ve prosedürler üniver- } \\
\text { sitenizin bütün süreçlerinin her biri için geliști- } \\
\text { rilmekte ve uygulanmaktadır. }\end{array}$ & 3,2 & 35,5 & 24,5 & 35,5 & 1,3 & 2,96 & \pm & 0,94 \\
\hline $\begin{array}{l}\text { Soru 6: Personel sayısının yetersizliği nede- } \\
\text { niyle görevler ayrılığı ilkesinin tam olarak uy- } \\
\text { gulanamadığı birimlerin yöneticileri risklere } \\
\text { karșı gerekli önlemleri alamamaktadır. }\end{array}$ & 1,3 & 25,8 & 14,8 & 51,0 & 7,1 & 3,37 & \pm & 0,98 \\
\hline FAKTÖR 4: BILGI VE İLETișiM & & & & & & & \pm & \\
\hline $\begin{array}{l}\text { Soru 7: Üniversitede, gelișen bilgi ihtiyaçları- } \\
\text { nı belirleme mekanizmaları yeterince mevcut } \\
\text { değildir. }\end{array}$ & 1,9 & 29,7 & 21,3 & 43,9 & 3,2 & 3,27 & \pm & 0,89 \\
\hline $\begin{array}{l}\text { Soru 8: Bilgi iletișim ağı üniversitenin ama- } \\
\text { cına yönelik ve ișlevsel olarak tasarlanmıștır. }\end{array}$ & 1,3 & 23,9 & 23,2 & 49,7 & 1,9 & 3,27 & \pm & 0,78 \\
\hline FAKTÖR 5: IZLLME & & & & & & & \pm & \\
\hline $\begin{array}{l}\text { Soru 9: Yönetim, iș ve ișlemler için perfor- } \\
\text { mans izleme sistemi olușturmuștur. }\end{array}$ & 9,7 & 57,4 & 16,1 & 15,5 & 1,3 & 3,01 & \pm & 1,10 \\
\hline $\begin{array}{l}\text { Soru 10: Periyodik olarak kontrollerin ișleyiși } \\
\text { ve genel etkinliği yeterince gözden geçirilme- } \\
\text { mektedir. }\end{array}$ & 0,6 & 24,5 & 14,8 & 56,8 & 3,2 & 2,41 & \pm & 0,91 \\
\hline $\begin{array}{l}\text { FAKTÖR 6: DENETIM PROGRAMININ } \\
\text { ETKINLIGGi }\end{array}$ & & & & & & & \pm & \\
\hline $\begin{array}{l}\text { Soru 1 1: Süreçlerin denetimi sırasında "birey- } \\
\text { sel çalıșma planı" gerek görüldüğünde revize } \\
\text { edilmektedir. }\end{array}$ & 1,3 & 7,7 & 9,7 & 66,5 & 14,8 & 2,62 & \pm & 1,07 \\
\hline $\begin{array}{l}\text { Soru 12: Saha çalıșmasında yer alan örnek- } \\
\text { lem sayısı azaldıkça, denetim programının } \\
\text { etkinliği artmaktadır. }\end{array}$ & 11,0 & 47,1 & 14,8 & 23,2 & 3,9 & 2,64 & \pm & 1,08 \\
\hline
\end{tabular}




\begin{tabular}{|l|c|c|c|c|c|c|c|c|}
\hline $\begin{array}{l}\text { Soru 13: Bireysel çalıșma planında denetçi } \\
\text { üzerindeki zaman baskısı arttıça denetim } \\
\text { etkinliği azalmaktadır. }\end{array}$ & - & 16,1 & 5,2 & 71,6 & 7,1 & 3,70 & \pm & 0,82 \\
\hline $\begin{array}{l}\text { Soru 14: Bireysel çalıșma planında test edi- } \\
\text { lecek unsurların sayısı azaldıkça, denetim } \\
\text { programının etkinliği artmaktadır. }\end{array}$ & 5,8 & 38,1 & 11,0 & 40,0 & 5,2 & 3,01 & \pm & 1,10 \\
\hline GENEL ORTALAMA & \multicolumn{7}{|c|}{$3,03 \pm 0.35$} \\
\hline
\end{tabular}

Ölçeğe verilen cevaplar genel ortalaması 3,03 olarak elde edilmiștir.

\section{Açıklayıcı Faktör Analizi}

Faktör analizi, birbiriyle ilișki halindeki p tane değișkeni bir araya getirerek az sayıda ilișkisiz ve kavramsal olarak anlamlı yeni değișkenler (faktörler, boyutlar) bulmayı, keșfetmeyi amaçlayan çok değișkenli bir istatistiktir (Büyüköztürk, Çakmak, Akgün, Karadeniz, \& Demirel, 2012). Ölçeklere yönelen açıklayıcı faktör analizinde ilk olarak verilerin faktör analizine uygunluk durumu değerlendirilmiștir. Bu noktada veri seti Kaiser-Meyer-Olkin (KMO) örneklem yeterliğinin -iyi düzey olan- 0.70 değerinin üzerinde ve 0.915 bulunmuștur. Analize tabi olan değișkenlerin tutarlılıklarını ölçen Bartlett küresellik testi istatistiki olarak anlamlı ( $\nabla 2=$ 2645,03 ve $p=.000$ ) bulunmuș; açıklayıcı faktör analizinde kullanılacak örneklemin yeterli olduğu ve ölçekte yer alan ifadelerin iç tutarlığının sağlandığı görülmüștür.

Veri setinin uygunluğunun yapılan testlerle onaylanmasından sonra faktör yapısının ortaya konulması amacıyla faktör tutma yöntemi olarak varimax döndürme metodu ve temel bileșenler analizi yöntemi uygulanmıștır. Toplam varyansın \%77,3'ünü açıklayan 6 faktörlük bir yapı belirlenmiștir. Faktör analizi sonucunda çıkarım sütununda değeri 0,20'un altında kalan soru bulunmadığı için önerme dıșarıda bırakılmamıștır. 
Tablo 4: Açıklayıcı Faktör Analizi Sonuçları

\begin{tabular}{|c|c|c|}
\hline \multirow{2}{*}{ FAKTÖR 1: KONTROL ORTAMI } & $\begin{array}{c}\text { Açıkladığı } \\
\text { varyans: } 19,6\end{array}$ & $\begin{array}{c}\text { Cronbachalpha } \\
\text { (CA):0.91 }\end{array}$ \\
\hline & $\begin{array}{l}\text { Faktör } \\
\text { yükü }\end{array}$ & $\begin{array}{c}\text { Madde } \\
\text { Silinirse CA }\end{array}$ \\
\hline $\begin{array}{l}\text { Soru 1: Üniversitenin etik ilkelere bağlılığı, üst yönetim tarafın- } \\
\text { dan çalıșanlara hem sözle hem de eylemsel olarak iletilir. }\end{array}$ & 0.58 & 0.90 \\
\hline $\begin{array}{l}\text { Soru 2: Üniversitenin organizasyonel yapısı görevler ayrılığı } \\
\text { ilkesine dayanmaktadır. }\end{array}$ & 0.70 & 0.87 \\
\hline \multirow{2}{*}{ FAKTÖR 2: RISK DEĞERLENDIRME } & $\begin{array}{c}\text { Açıkladığı } \\
\text { varyans: } 17,2\end{array}$ & $\begin{array}{l}\text { Cronbachalpha } \\
\text { (CA):0.90 }\end{array}$ \\
\hline & $\begin{array}{l}\text { Faktör } \\
\text { yükü }\end{array}$ & $\begin{array}{c}\text { Madde } \\
\text { Silinirse CA }\end{array}$ \\
\hline $\begin{array}{l}\text { Soru 3: Üniversitenin hedefleri sorumlu personel tarafından ko- } \\
\text { lay anlașilabilir niteliktedir. }\end{array}$ & 0.64 & 0.89 \\
\hline $\begin{array}{l}\text { Soru 4: Üniversitenin iç kontrol sistemi, kurum hedeflerine ula- } \\
\text { șlmasına mani olacak engelleri (hile dahil) bertaraf edecek bi- } \\
\text { çimde tasarlanmıștır. }\end{array}$ & 0.31 & 0.90 \\
\hline \multirow{2}{*}{ FAKTÖR 3. KONTROL FAALIYETLERI } & $\begin{array}{c}\text { Açıkladığı } \\
\text { varyans: } 14,8\end{array}$ & $\begin{array}{c}\text { Cronbachalpha } \\
\text { (CA):0.92 }\end{array}$ \\
\hline & $\begin{array}{l}\text { Faktör } \\
\text { yükü }\end{array}$ & $\begin{array}{c}\text { Madde } \\
\text { Silinirse CA }\end{array}$ \\
\hline $\begin{array}{l}\text { Soru 5: Uygun politika ve prosedürler üniversitenizin bütün sü- } \\
\text { reçlerinin her biri için geliștirilmekte ve uygulanmaktadır. }\end{array}$ & 0.48 & 0.91 \\
\hline $\begin{array}{l}\text { Soru 6: Personel sayısının yetersizliği nedeniyle görevler ayrılığı } \\
\text { ilkesinin tam olarak uygulanamadığı birimlerin yöneticileri risk- } \\
\text { lere karșı gerekli önlemleri alamamaktadır. }\end{array}$ & 0.55 & 0.88 \\
\hline \multirow{2}{*}{ FAKTÖR 4: BILGI VE ILETIȘIM } & $\begin{array}{c}\text { Açıkladığı } \\
\text { varyans: } 10.4 \\
\end{array}$ & $\begin{array}{c}\text { Cronbachalpha } \\
\text { (CA):0.91 }\end{array}$ \\
\hline & $\begin{array}{l}\text { Faktör } \\
\text { yükü }\end{array}$ & $\begin{array}{c}\text { Madde } \\
\text { Silinirse CA }\end{array}$ \\
\hline $\begin{array}{l}\text { Soru 7: Üniversitede, gelișen bilgi ihtiyaçlarını belirleme meka- } \\
\text { nizmaları yeterince mevcut değildir. }\end{array}$ & 0.62 & 0.84 \\
\hline $\begin{array}{l}\text { Soru 8: Bilgi iletișim ağı üniversitenin amacına yönelik ve ișlev- } \\
\text { sel olarak tasarlanmıștır. }\end{array}$ & 0.78 & 0.89 \\
\hline \multirow{2}{*}{ FAKTÖR 5: IZZLEME } & $\begin{array}{c}\text { Açıkladığı } \\
\text { varyans: } 9,7\end{array}$ & $\begin{array}{l}\text { Cronbachalpha } \\
\text { (CA):0.90 }\end{array}$ \\
\hline & $\begin{array}{l}\text { Faktör } \\
\text { yükü }\end{array}$ & $\begin{array}{c}\text { Madde } \\
\text { Silinirse CA }\end{array}$ \\
\hline $\begin{array}{l}\text { Soru 9: Yönetim, iș ve ișlemler için performans izleme sistemi } \\
\text { olușturmuștur. }\end{array}$ & 0.83 & 0.87 \\
\hline $\begin{array}{l}\text { Soru 10: Periyodik olarak kontrollerin ișleyiși ve genel etkinliği } \\
\text { yeterince gözden geçirilmemektedir. }\end{array}$ & 0.72 & 0.90 \\
\hline
\end{tabular}




\begin{tabular}{|l|c|c|}
\hline \multirow{2}{*}{ FAKTÖR 6: DENETiM PROGRAMININ ETKiNLiĞi } & $\begin{array}{c}\text { Açıladığı } \\
\text { varyans: 5.6 }\end{array}$ & $\begin{array}{c}\text { Cronbachalpha } \\
\text { (CA):0.92 }\end{array}$ \\
\cline { 2 - 3 } & Faktör yükü̈ & $\begin{array}{c}\text { Madde } \\
\text { Silinirse } \\
\text { CA }\end{array}$ \\
\hline $\begin{array}{l}\text { Soru 11: Süreçlerin denetimi sırasında "bireysel çalıșma planı" } \\
\text { gerek görüldüğ̈unde revize edilmektedir. }\end{array}$ & 0.87 & 0.86 \\
\hline $\begin{array}{l}\text { Soru 12: Saha çalıșmasında yer alan örneklem sayısı azaldık- } \\
\text { ça, denetim programının etkinliği artmaktadır. }\end{array}$ & 0.74 & 0.91 \\
\hline $\begin{array}{l}\text { Soru 13: Bireysel çalıșma planında denetçi üzerindeki zaman } \\
\text { baskısı arttıkça denetim etkinliği azalmaktadır. }\end{array}$ & 0.81 & 0.87 \\
\hline $\begin{array}{l}\text { Soru 14: Bireysel çalıșma planında test edilecek unsurların sayı- } \\
\text { sı azaldıkça, denetim programının etkinliği artmaktadır. }\end{array}$ & 0.88 & 0.90 \\
\hline
\end{tabular}

Elde edilen faktörlere ilișkilerin belirlenmesi amaçlı korelasyon ve regresyon analizi uygulanmıștır.

\subsubsection{Regresyon analizi sonuçları}

Tablo 5: Regresyon Analizi Tahmin Sonuçları

\begin{tabular}{|c|c|c|c|c|}
\hline \multicolumn{5}{|c|}{ Bağımlı değișken: Denetim programlarının etkinliği } \\
\hline Bağımsız Değișkenler & Katsayı & St. hata & t istatistiği & p(anlamlılık) \\
\hline Sabit & 0.226128 & 0.070027 & 3.229146 & $0.0015^{*}$ \\
\hline Kontrol ortamı & 0.551903 & 0.074263 & 7.431732 & $0.0000^{*}$ \\
\hline Risk değerlendirme & 0.135083 & 0.075539 & 1.788249 & 0.0758 \\
\hline Kontrol faaliyetleri & 0.487613 & 0.065612 & 7.431732 & $0.0000^{*}$ \\
\hline Bilgi ve iletișim & 0.045175 & 0.070718 & 0.638808 & 0.5239 \\
\hline İzleme & 0.301942 & 0.073412 & 4.113002 & $0.0001^{*}$ \\
\hline
\end{tabular}

*0,05 için anlamlı değișken

Tablo 5'den görüleceği üzere; her regresyon için varsayımların testleri (diagnostik testler) uygunluk göstermiș, otokorelasyon ve heteroskedasite problemleri olmadığı için sonuçlar yorumlanabilir özellikte elde edilmiștir. Çoklu doğrusal bağlantı için VIF kriterlerine bakılmıș, sorun olmadığı belirlenmiștir. Hata payları normal dağılımlıdır.

Modelin bağımsız değișkenleri bağımlı değișken olan denetim programlarının etkinliği değișkenini \%55,9 açıklamaktadır. "Risk değerlendirme" ve "bilgi-iletișim" bileșenleri ile denetim programlarının etkinliği arasında anlamlı bir ilișki yoktur. Buna karșılık kontrol ortamı dene- 
timin etkinliğini \%55 arttırmakta, kontrol faaliyetleri \%48 arttırmakta, izleme \%30 artırmaktadır. Yüksek etki kontrol ortamı değișkeninden, düșük etki izleme değișkeninden kaynaklıdır.

Sonuç itibariyle, regresyon analizi sonuçlarının da bir önceki bölümde korelasyon analizi sonuçları ile aynı paralelde olduğu gözlenmektedir.

\section{Sonuç}

Devlet üniversitelerindeki iç kontrol sistemi bileșenlerinin iç denetim programı üzerindeki etkinliğini değerlendirmeyi amaçlayan çalıșmada, iç denetim birimlerine yöneltilen anket bulgularından hareketle ve öz itibarıyla bileșenlerin bir bölümü itibarıyla anlamlı ilișki bulunduğu sonucuna ulașılmıștır.

Uygulanan anket, iç kontrol sisteminin beș bileșeni ilgili olarak yer verilen sorulardan olușmaktadır. Çalıșılan ölçeğin dağılımı incelendikten sonra güvenirliği değerlendirilmiș olup, hipotezlerin testi için faktör analizi uygulanarak, elde edilen faktörlere korelasyon ve regresyon analizi uygulanmıștır. Bu çerçevede belirlenmeye çalıșilan ilișkilerden hareketle, iç kontrol sistemi bileșenlerinden, "kontrol ortamı", "kontrol faaliyetleri" ile "izleme" bileșenleri itibarıyla anlamlı ilișki tespit edilirken, "risk değerlendirme" ile "bilgi ve iletișim" bileșenlerinin denetim programı etkinliği üzerinde anlamlı bir ilișkiye sahip görünmediği sonuçlarına ulașılmıștır.

Bu sonuçların, iç denetim birimlerinin yaklașımı itibarıyla, devlet üniversiteleri iç kontrol sistemlerinin "risk değerlendirme" ile "bilgi ve iletișim" değișkenleri itibarıyla zayıflığına ișaret ettiği değerlendirilmiștir. Çünkü denetim programlarının etkinliğinde tüm așamalar önemli bulunmakla birlikte, iç kontrol sisteminin iki bileșeni itibarıyla zayıflıkların söz konusu olması nedeniyle denetim programının tasarım așaması itibarıyla olumsuz yönde etkileneceği düșünülmektedir.

Bu sonuçlar aynı zamanda devlet üniversitelerinde her birim özelinde yönetim süreçlerinin tüm fonksiyonlarının etkinliğinin irdelenmesi gereğine ișaret etmektedir. Çünkü yönetim süreçlerinde planlama - kontrol döngüsü itibarıyla organizasyon, koordinasyon ve yürütme fonksiyonlarına yönelik risk değerlendirmelerinin, gelecek dönemlere ilișkin denetim programlarının hazırlanmasında anahtar rolü olduğu düșünülmektedir. Șüphesiz bu bağlamda bilgi ve iletișim değișkenlerinin ve geri bildirimlerin etkinliğinin de önemli role sahip olduğu değerlendirilmektedir. 
Bu çalıșma kısıtları da değerlendirilmek suretiyle, bundan sonra yapılacak araștırmalarda, gerek iç kontrol sistemlerinin farklı bileșenleri gerekse iç denetim programlarının etkinliği itibarıyla, farklı örneklem hedeflerinin belirlenmesinin önem tașıdığı değerlendirilmektedir.

\section{Kaynakça}

Akyel, R. (2010). Türkiye'de İç Kontrol Kavramı, Unsurları ve Etkinliğinin Değerlendirilmesi. Yönetim ve Ekonomi, Celal Bayar Üniversitesi IïBF Dergisi, 17(1), 83-98.

Büyüköztürk, Ș., Çakmak, E. K., Akgün, Ö. E., Karadeniz, Ș., \& Demirel, F. (2012). Bilimsel Araștırma Yöntemleri (13 b.). Ankara: Pegem Yayınları.

COSO. (2013). Internal Control - Integrated Framework. 07 10, 2019 tarihinde hitp:// www.coso.org adresinden alındı

Cömert, N. (2016, June). İșletmelerde Kontrol ve Denetim Kavramlarının Doğru Kullanılması Amacına Yönelik Kavramsal Bir İnceleme. Marmara Üniversitesi Marmara Business Review, 1(1), 1-20.

Dabbağoğlu, K. (2009). İç Kontrol Sistemi. Jurnal of Qafqaz University(26), 109-1 15.

Daniel, L. S. (1990). The Effects of Time Pressure and Audit Program Structure on Audit Performance. 28(2), 267-285.

Erdoğan, S. (2009). İç Kontrol Sistemi: Kamu Iktisadi Teșebbüsleri İçin İç Kontrol Modeli Onerisi, DPT Uzmanlık Tezleri Yayın No: 2799. Ankara.

Hermanson, D. R., Smith, J. L., \& Stephens, N. M. (2012). How Effective Are Organizations' Internal Control? Inside Into Specific Internal Control Elements. American Accounting Association, 6(1), A31-A50.

İbiș, C., \& Çatıkkaș, Ö. (2012, Nisan-Haziran ). İșletmelerde İç Kontrol Sistemine Genel Bakıș. Sayıștay Dergisi (85), 95-121.

iSMMMO. (2013). KOBi'lerde İç Denetim İçin Pratik Bilgiler. İstanbul: ISMMMO Yayınları.

Karagiorgos, T., Drogalas, G., \& Giovanis, N. (2011). Evaluation of the Effectiveness of Internal Audit in Greek Hotel Business. 4(1), 19-34.

Kiracı, M. (2003, Aralık). Faaliyet Denetimi ile İç Kontrol ilișkisi. Osmangazi Üniversitesi Sosyal Bilimler Dergisi, 4(2), 67-78.

Likert, R. (1932). A Technique for the measurement of attitudes. Archives of Psychology, 22(140), 5-55.

Liv, T. (2005). The Case Analysis on Failures of Enterprise Internal Control in Mainland China. Journal of American Academy of Business, Cambridge, 7(1), 92-99.

Sawalqa, F. A., \& Qtish, A. (2012). Internal Control and Audit Program Effectiveness. Empirical Evidence from Jordan. International Business Research, 5(9), s. 128-137. 
T.C. Maliye Bakanlığı Bütçe ve Mali Kontrol Genel Müdürlüğü. (2014). Kamu İç Kontrol Rehberi - versiyon 1.0. 1-124.

Tosun, K. (1992). İșletme Yönetimi (6 b.). İstanbul: Savaș Yayınları. 